\title{
Effectiveness of commonly used high level disinfectants on bacteria responsible for hospital acquired infections in Sri Jayewardenepura General Hospital, Sri Lanka.
}

\author{
GCK Boteju ${ }^{1}$, GGYH Weerasinghe ${ }^{1}$, HKAP Gunasekara ${ }^{1}$, SK Jayatilleke ${ }^{2}$, \\ RD Widanagamage ${ }^{1}$, WAC Karunarathna ${ }^{1}$ \\ Sri Lankan Journal of Infectious Diseases 2020 Vol.10 (1):38-47 \\ DOI: http://dx.doi.org/10.4038/sljid.v10i1.8257
}

\begin{abstract}
Introduction: Hospital-acquired infections (HAIs) cause high morbidity and mortality in patients throughout the world. Nosocomial pathogens can be transmitted through contaminated instruments and surfaces. Disinfectants play a crucial role in preventing HAIs. This study focuses on two high level disinfectants designated 'disinfectant 1' which contains primarily peracetic acid and 'disinfectant 2' which contains primarily didecyldimethylammonium chloride.
\end{abstract}

Objective: To determine the effectiveness of commonly used high level disinfectants on bacteria responsible for causing HAIs in Sri Jayewardenepura General Hospital, Sri Lanka (SJGH), on different surfaces.

Method: Data of the Infection Prevention and Control (IPC) unit of SJGH was traced back to identify bacteria causing HAIs from $1^{\text {st }}$ January to $31^{\text {st }}$ July 2018 . This experimental study was conducted for disinfectant 1 and 2 according to the quantitative carrier test (European Standard EN 14561:2006). Disinfectants were tested at three different concentrations on glass, stainless steel and rexine surfaces against the commonest three bacteria responsible for causing HAIs in SJGH.

Results: Coliforms, Acinetobacter species and Staphylococcus aureus were the three most common bacteria responsible for causing HAIs in SGJH. Surgical site infections were the predominant type of HAI and Intensive Care Units (ICUs) were identified as having the highest prevalence of HAIs. Both high level disinfectants achieved a Microbicidal Effect (ME) value of 5 as per 'clean disinfectants' in manufacturer recommended dilutions and passed the test against Escherichia coli, Acinetobacter spp. and $S$. aureus under both clean and dirty condition on all three tested surfaces. However, bacterial colonies of all 3 test organisms were detected after both disinfectant 1 and 2 use. Effect of disinfectant 1 was

\footnotetext{
${ }^{1}$ Department of Medical Laboratory Sciences, Faculty of Allied Health Sciences, General Sir John Kotelawala Defence University, Sri Lanka

${ }^{2}$ Sri Jayewardenepura General Hospital, Nugegoda, Sri Lanka

Address for correspondence: Chavan Boteju, Department of Medical Laboratory Sciences, Faculty of Allied Health Sciences, General Sir John Kotelawala Defence University. Telephone:+94766630101

Email:chavanboj@gmail.com (iD) https://orcid.org/0000-0003-4693-8961

Received 20 July 2019 and revised version accepted 4 December 2019

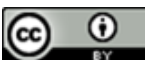

This an open-access article distributed under the terms of the Creative Commons Attribution License, which permits unrestricted use, distribution, and reproduction in any medium, provided the original author and source are credited.
} 
poor in manufacturer recommended concentrations on glass, stainless steel and rexine surfaces. ME of disinfectant 2 was considerably higher when compared to disinfectant 1.

Conclusion: Although the manufacturer stated test standard was achieved for both disinfectants, the presence of residual bacteria after high level disinfectant use on different surfaces is not acceptable.

Keywords: HAIs, Disinfectants, Microbicidal Effect, Surfaces, High level disinfection

\section{Introduction}

A Hospital Acquired Infection (HAI) is an infection occurring in a patient during the process of care in a hospital which was not present at the time of admission. ${ }^{1}$ The prevalence of HAIs have risen irrepressibly, resulting in high morbidity and mortality rates along with elevated healthcare costs., ${ }^{2,3}$ Patients in ICUs, burns units, transplant units and neonatal units are at a higher risk of acquiring HAIs. ${ }^{1}$

Most common nosocomial pathogens have the ability to persist on inanimate surfaces for a prolonged period of time, even after exposure to common currently used disinfectants. These act as a source of infection transmission in the healthcare environment. ${ }^{4}$ Clinically isolated nosocomial Acinetobacter species expressed increased minimum inhibitory concentrations towards commonly used disinfectants. ${ }^{5}$ It is therefore important to monitor the resistance levels of these organisms in order to prevent transmission within health care settings which can result in outbreaks of nosocomial infection. ${ }^{5}$ Also clinically isolated methicillin resistant Staphylococcus aureus (MRSA) strains have shown a progressive resistance towards many disinfectants. ${ }^{6}$

It is important to identify the most common bacteria causing HAIs and to determine the effectiveness of commonly used disinfectants on bacteria responsible for causing HAIs on different surfaces in Sri Jayewardenepura General Hospital, Sri Lanka (SJGH).

\section{Methods}

Data of the Infection Prevention and Control (IPC) unit of SJGH was traced back from $1^{\text {st }}$ of January to $31^{\text {st }}$ July 2018 and a total of 95 HAIs were identified. Of the 95 total incidents, the three most common pathogens causing HAIs were coliforms, Acinetobacter spp and $S$. aureus. Of the total 95 infections, 38 (40.02\%) were caused by coliforms, for which E. coli was taken as the surrogate organism, 24 (25.28\%) were caused by Acinetobacter spp. and $10(10.54 \%)$ were caused by S. aureus.

The study was conducted according to the European Standard EN 14561:2006, Quantitative carrier test for the evaluation of bactericidal activity for instruments used in the medical area (phase 2, step 2). ${ }^{7}$ The disinfectant effectiveness testing was performed in the microbiology laboratory, Faculty of Medicine, General Sir John Kotelawala Defense University, Ratmalana.

The two most commonly used high level disinfectants in SJGH were used as test disinfectants. The dilutions were prepared from a stock solution as gradients of the in-use concentrations. Disinfectant 1 contained per acetic acid, acetic acid and hydrogen peroxide corrosion inhibitors and its hospital in-use dilution is the manufacturer recommended 
dilution of $6 \%$. Disinfectant 2 contained 2-aminoethanol, didecyldimethylammonium chloride and bis (3-aminopropyl) dodecylamine. The hospital in-use dilution is half the manufacturer recommended dilution of $2.5 \%(1.25 \%)$. Test concentrations selected were the hospital in-use dilution, half the hospital in-use dilution and 1.5 times concentrated inuse dilution.

\section{Preparation of bacterial cell suspension}

Bacterial cell suspensions were prepared by inoculating $10 \mathrm{ml}$ of nutrient broth (diluent) with loopfuls of a second subculture of the test organism. The bacterial suspensions were adjusted to an optical density of 0.08 at $680 \mathrm{~nm}$, which was similar to a concentration of $10^{8} \mathrm{cfu} / \mathrm{mL} .^{5}$ For counting of colonies, $10^{-12}$ dilutions of the test suspension were prepared using diluent.

Disinfectants were tested under clean condition (absence of organic substances) and dirty condition (contain organic substances). To obtain the dirty condition $5 \mathrm{~mL}$ of bacterial suspensions were mixed with $2.5 \mathrm{~mL}$ of sterile serum and $2.5 \mathrm{~mL}$ of red cell concentrate to mimic clinical situations. ${ }^{7}$

\section{Inoculation of the carriers}

Glass, stainless steel and rexine surfaces were thoroughly washed with distilled water and sterilized by autoclaving. Then $0.05 \mathrm{~mL}$ of each bacterial suspension were pipetted onto an $1 \mathrm{~cm}^{2}$ area of the glass, stainless steel and rexine surfaces. After the surfaces were visibly air dried, the carrier was immersed in $10 \mathrm{~mL}$ of test disinfectant and mixed by vortexing for 15 seconds and left for the contact time recommended by the disinfectant manufacturer (10 minutes). The carrier was then transferred to $10 \mathrm{~mL}$ of neutralizing solution (phosphate buffer saline $0.25 \mathrm{~mol} / \mathrm{l}$ ) and mixed by vortexing for 15 seconds. After 5 minutes in the neutralizing solution, $0.1 \mathrm{~mL}$ from each solution was cultured on nutrient agar plates using the spread plate technique.

The number of colonies surviving on each plate was counted after overnight incubation at $37{ }^{\circ} \mathrm{C}$. A control test was done by replacing disinfectant with distilled water to determine the initial survival of bacteria on each surface type. All experiments were repeated four times and average number of viable colonies were determined.

\section{Interpretation of results}

Bactericidal activity of a disinfectant is determined by the measurement of Microbicidal Effect (ME).

\section{Microbicidal effect $(M E)=\log N_{w}-\log N$}

$\mathrm{N}_{\mathrm{w}}=$ number of initial colony counts cfu/mL bacteria cell suspension in the water control $\mathrm{N}=$ number of $\mathrm{cfu} / \mathrm{mL}$ in bacterial suspension after immersion in the disinfectant

$$
\begin{aligned}
& \mathrm{N}_{\mathrm{w}}=\frac{\mathrm{c} \times 10}{\mathrm{n} \times \mathrm{d}} \\
& \mathrm{c}=\text { sum of viable counts values taken into account }\left(\mathrm{V}_{\mathrm{c}}\right) \\
& \mathrm{n}=\text { number of } \mathrm{V}_{\mathrm{c}} \text { values taken into account } \\
& \mathrm{d}=\text { the dilution factor corresponding to the } 1 \mathrm{st} \text { dilution taken into account } \\
& 10=\text { tenfold higher than the } \mathrm{V}_{\mathrm{c}} \text { values due to the addition of neutralizer }
\end{aligned}
$$


$\mathrm{ME} \geq 5=$ Pass

$\mathrm{ME}<5=$ Fail

The data was entered to Microsoft Excel 2016 and all IPC data were analyzed using descriptive statistics.

\section{Results}

A total of 95 HAIs was recorded during the study period in SJGH. The three most common pathogens causing HAIs were identified as coliforms (40.02\%), Acinetobacter spp. (25.28\%) and S. aureus (10.54\%). Enterococcus (1.05\%) and Flavobacterium (1.05\%) were reported as the least common pathogens causing HAIs.

Surgical site infections (SSI) were the predominant (49.47\%) cause of HAIs. Of the 95 HAI incidents, $18.86 \%$ were catheter related blood stream infections (CRBSI) while only $16.84 \%$ were hospital acquired pneumonia (HAP). Other HAIs included ventilator associated pneumonia (VAP) at $9.47 \%$ and catheter associated urinary tract infections (CAUTI) at $4.21 \%$.

Of the 95 total incidents, 46 (48.42\%) were reported from the Cardiothoracic Intensive Care Unit (CTICU), ICU, Neonatal Intensive Care Unit (NICU) and Neurosurgical Intensive Care Unit (NSICU).

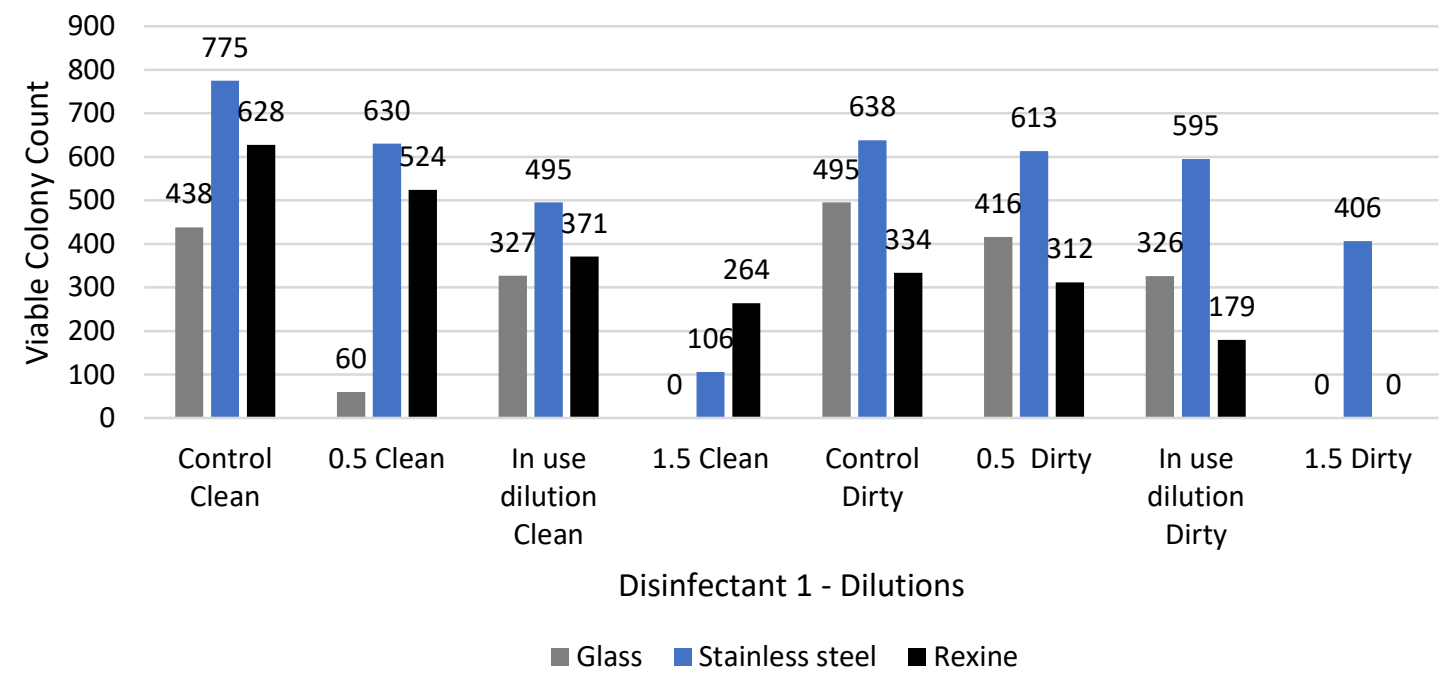

Figure 1: Colony counts of $E$. coli adherent on the three test surfaces after being treated with disinfectant 1 under clean and dirty condition

As shown in Figure 1 the viable colony counts of $E$. coli was not reduced by the in-use dilution under both clean and dirty conditions after being treated with disinfectant 1 . Even at the 1.5 dilution, there were bacterial colonies remaining on the stainless steel and rexine surfaces under clean conditions. The stainless steel surface showed the highest colony counts, demonstrating reduced effectiveness of disinfectant 1 on this surface compared to the other two surfaces. 


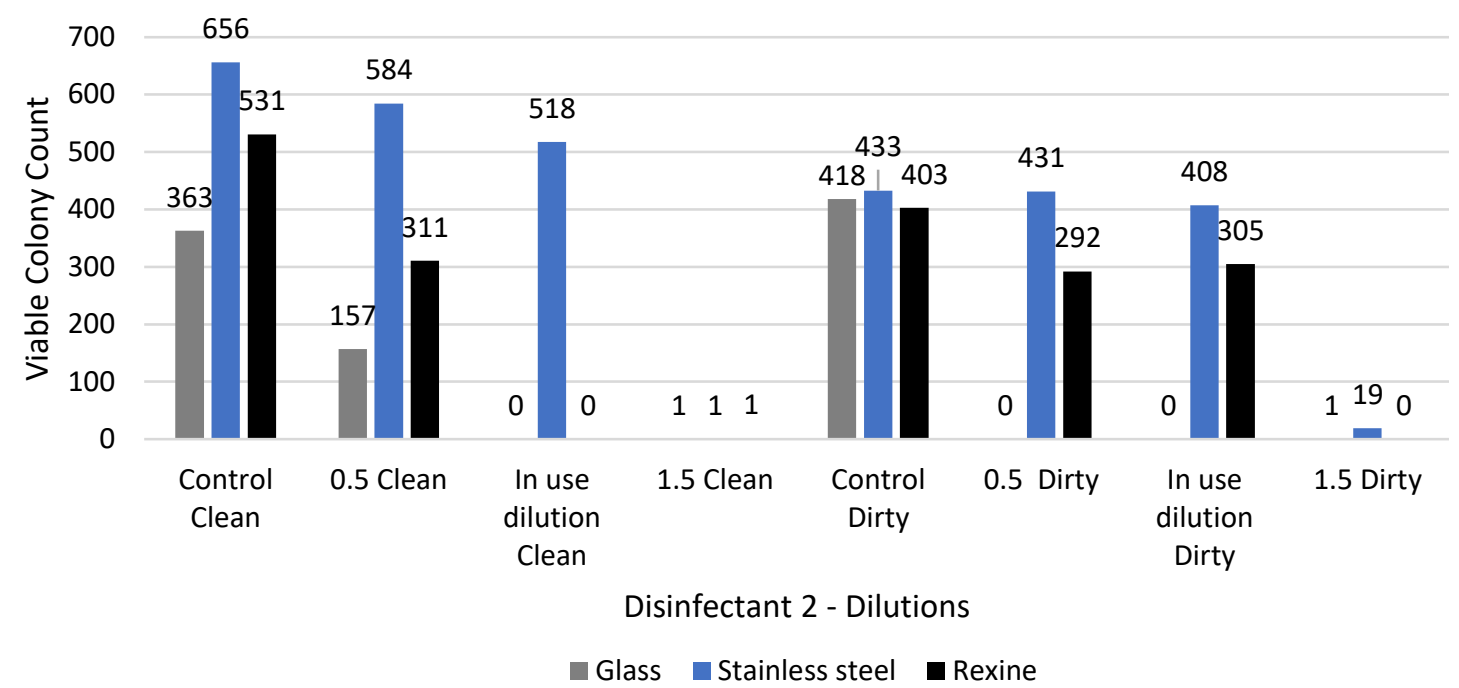

Figure 2: Colony counts of $E$. coli adherent on the three test surfaces after being treated with disinfectant 2 under clean and dirty condition

As shown in Figure 2, 1.5 concentration of disinfectant 2 gave the lowest colony counts, demonstrating high effectiveness. The glass surfaces showed lower colony counts when compared with the other two surfaces.

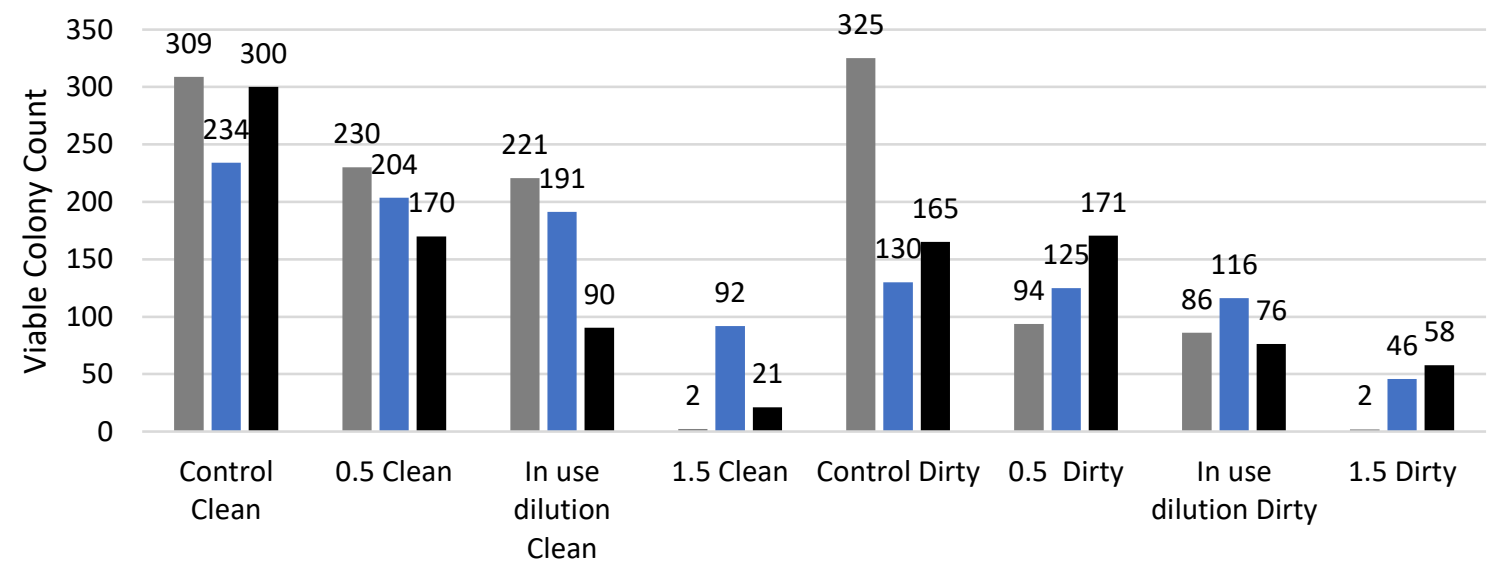

Disinfectant 1 - Dilutions

- Glass $\quad$ Stainless steel $\quad$ Rexine

Figure 3: Colony counts of Acinetobacter spp. adherent on the three test surfaces after being treated with disinfectant 1 under clean and dirty condition

As shown in Figure 3, at the in-use dilution, disinfectant 1 did not reduce the colony count considerably under both clean and dirty conditions. Even at 1.5 times concentration, viable colonies of Acinetobacter spp. remained on stainless steel and rexine surfaces under both conditions. 


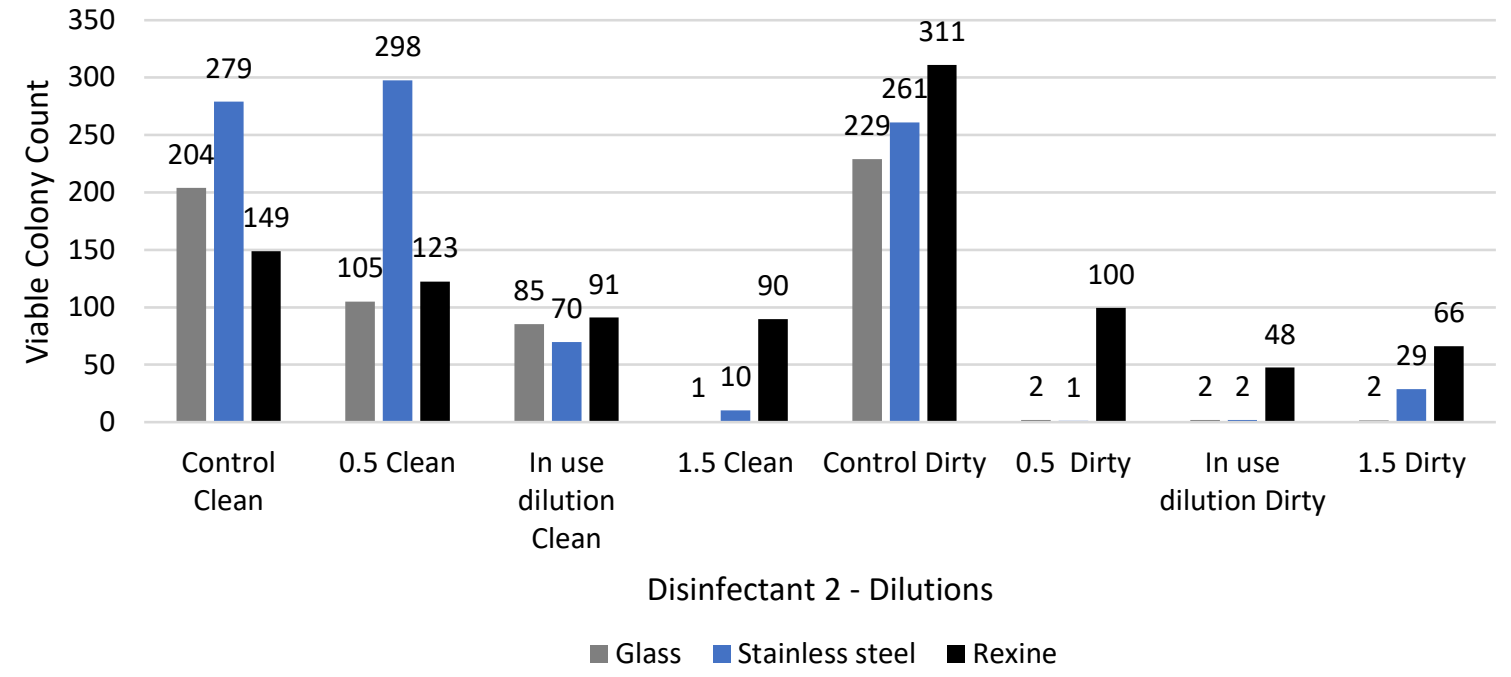

Figure 4: Colony counts of Acinetobacter spp. adherent on the three test surfaces after being treated with disinfectant 2 under clean and dirty condition

Figure 4 shows that bacterial colonies of Acinetobacter spp. remained even at in-use dilution of disinfectant 2 . There were always a notable number of colonies on the rexine surfaces.

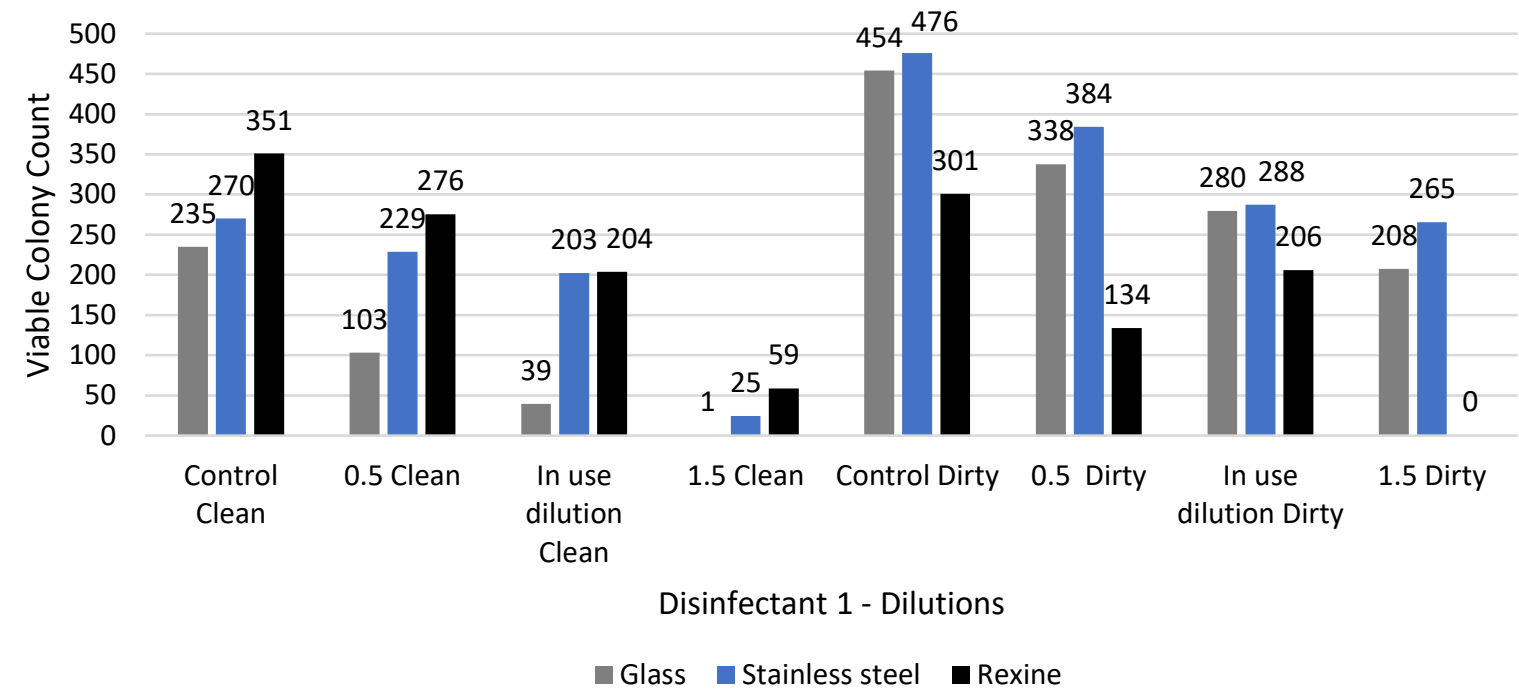

Figure 5: Colony counts of $S$. aureus adherent on the three test surfaces after being treated with disinfectant 1 under clean and dirty condition

As shown in Figure 5, there were a considerable number of colonies of $S$. aureus remaining on the three surfaces at the in-use dilution of disinfectant 1 . There was a higher colony count in the test under dirty conditions compared to clean conditions. 


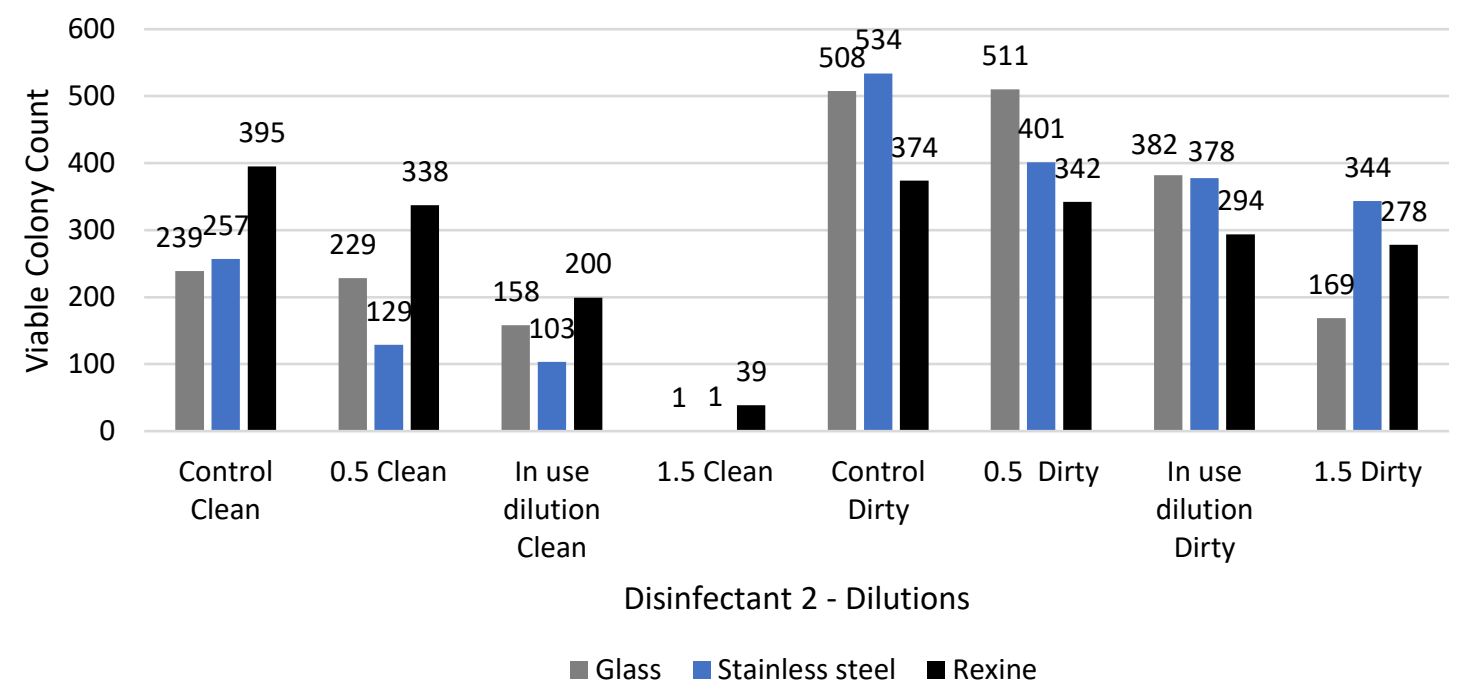

Figure 6: Colony counts of $S$. aureus adherent on the three test surfaces after being treated with disinfectant 2 under clean and dirty condition

Figure 6 shows that there were significant number of colonies remaining when tested under dirty condition compared to clean conditions with disinfectant 2 . At the 1.5 concentration, there were colonies remaining on the rexine surfaces under clean conditions.

Table 1: The Microbicidal Effect (ME) of disinfectant 1 and 2 against $E$. coli, Acinetobacter spp. and $S$. aureus at manufacturer recommended dilutions under clean and dirty conditions

\begin{tabular}{|l|l|c|c|c|c|c|c|}
\hline \multirow{3}{*}{ Condition } & \multirow{2}{*}{$\begin{array}{l}\text { Surface } \\
\text { type }\end{array}$} & \multicolumn{2}{|c|}{$\begin{array}{c}\text { Log reduction of initial colony } \\
\text { counts (ME) using disinfectant 1 }\end{array}$} & \multicolumn{2}{|c|}{$\begin{array}{c}\text { Log reduction of initial colony } \\
\text { counts (ME) using disinfectant 2 }\end{array}$} \\
\cline { 3 - 8 } & E. coli & $\begin{array}{c}\text { Acinetobacter } \\
\text { spp. }\end{array}$ & S. aureus & E. coli & $\begin{array}{c}\text { Acinetobacter } \\
\text { spp. }\end{array}$ & S. aureus \\
\hline \multirow{3}{*}{ Clean } & Glass & 5.13 & 5.15 & 5.78 & 7.68 & 7.43 & 7.5 \\
\cline { 2 - 8 } & $\begin{array}{l}\text { Stainless } \\
\text { steel }\end{array}$ & 5.19 & 5.09 & 5.13 & 8.12 & 6.43 & 7.31 \\
\cline { 2 - 8 } & Rexine & 5.23 & 5.52 & 5.24 & 7.73 & 5.22 & 6.01 \\
\hline \multirow{3}{*}{ Dirty } & Glass & 5.18 & 5.58 & 5.21 & 7.75 & 7.18 & 5.48 \\
\cline { 2 - 8 } & $\begin{array}{l}\text { Stainless } \\
\text { steel }\end{array}$ & 5.03 & 5.41 & 5.22 & 6.36 & 5.96 & 5.19 \\
\cline { 2 - 8 } & Rexine & 5.27 & 5.63 & 5.17 & 8.21 & 5.67 & 5.13 \\
\hline
\end{tabular}

To determine whether the disinfectant is effective or not it must achieve at least an ME value of $5 .^{8}$ Both high level disinfectants achieved ME value of 5 at manufacturer recommended dilutions and passed the test against $E$. coli, Acinetobacter spp. and S. aureus under both clean and dirty condition on all three surfaces (Table 1).

\section{Discussion}

Coliforms (40.02\%), Acinetobacter spp. (25.28\%) and S. aureus (10.54\%) were the three most common pathogens causing HAIs in the current study. E. coli $(30.7 \%)$, S. aureus $(12.3 \%)$ were the most frequently isolated pathogens in Europe. ${ }^{8}$ Similar results were 
observed in India with Acinetobacter spp. (34\%), and E. coli (15\%) being the predominant bacteria causing HAIs. ${ }^{9}$

We observed that the predominant type of HAI was SSI (49.47\%). This is in accordance with studies which stated that the SSI was the foremost infection in the general patient population in countries with limited resources. ${ }^{1}$

The findings of our study show that the highest prevalence of HAIs were recorded in ICUs. Forty six of the 93 total incidents $(48.42 \%)$ were reported from ICUs. Similar findings have been shown elsewhere, with HAI occurence in ICU settingsas high as $51 \%$ being reported. ${ }^{10}$ Approximately $30 \%$ of patients in ICUs in high-income countries were affected by at least one health care-associated infection while in low and middle income countries the frequency of affected patients in ICU was at least 2-3 fold higher. ${ }^{1}$ ICUs have the highest prevalence of HAIs due to mechanical ventilation, invasive procedures and immunocompromised status. Therefore, our study focused mainly on the disinfection process in ICUs.

Disinfectant 1 contained peracetic acid, acetic acid, hydrogen peroxide corrosion inhibitors and auxiliary substances. Peracetic acid has a wide spectrum of antimicrobial activity and acts as an oxidizing agent. Hydrogen peroxide denatures protein, disrupts cell-wall permeability and oxidizes sulfur bonds in proteins. ${ }^{11}$ Dodecylamine based products of disinfectant 2 destroy microorganisms by disrupting the RNA. ${ }^{12}$

Some surface-active antimicrobial compounds require longer exposure times or higher concentrations for comparable antimicrobial efficacy which also depends on the test organisms. $^{13}$

The effectiveness of disinfectant 2 was higher than that of disinfectant 1 towards $E$. coli. The study data showed that the highest effectiveness was achieved by disinfectant 2 as it demonstrated a reduced colony count of Acinetobacter spp. Using disinfectant 2, the colony counts of Acinetobacter spp. tested under dirty conditions was reduced to a greater extent than when tested in clean conditions. The detachment of discrete cell clusters due to mechanical forces could contribute to this unexpected finding. Vortexing is likely to serve as a mechanical force in this context. ${ }^{14}$

As several clinical isolates of Acinetobacter have developed augmented resistance to the recommended in-use concentration of multiple antimicrobials and disinfectants, it is worth checking the susceptibility to disinfectants if multidrug-resistant Acinetobacter spp. that are recurrently isolated in a local setting in order to prevent nosocomial outbreaks. ${ }^{5}$

In our study, higher colony counts of $S$. aureus was observed under the test dirty conditions when compared with clean conditions for both disinfectant 1 and 2. A possible explanation is that the viability increases if bacterial cells are dried in the presence of sugar, blood and serum. ${ }^{15}$ These bacteria participate in the surface adhesion process with variable chemical and physical intensity. ${ }^{14}$ Although the viability of Acinetobacter spp. and E. coli were increased in the presence of organic substances, detachment of their cell clusters were higher due to the different bacterial adhesion intensity which has specific interactions between a bacterium and a surface. 
The study showed that disinfectant 2 was more effective than disinfectant 1 against $\mathrm{S}$. aureus on all three surfaces in clean conditions. The requirement for effective cleaning before disinfection of endoscopes is therefore a mandatory requirement on reprocessing endoscopes. ${ }^{16}$ Even at the recommended dilution of disinfectant 2 , there were colonies on rexine surface, which suggests that disinfectant 2 is poorly effective on a rexine surface. Since clinically isolated MRSA strains have showed progressive resistance towards many disinfectants ${ }^{6}$, it is important to determine the susceptibility of clinical MRSA to various disinfectants to assess the control and preventive measures currently implemented in hospitals.

Bactericidal activity of a disinfectant is determined by the measurement of Microbicidal Effect (ME). It was calculated for each test organism only for the manufacturer recommended dilution for both disinfectants under clean and dirty conditions. A disinfectant must achieve an ME value of at least 5, ie: a 5- log reduction in viable count, to pass the test as per normal disinfectant. ${ }^{7}$ Both disinfectants reached ME values of 5 or over 5, though there were remaining bacterial colonies. These two disinfectants are recommended by manufacturers and used in SJGH as high level disinfectants.

High-level disinfection is defined as complete elimination of all microorganisms in or on an instrument, except for small numbers of bacterial spores, to prevent transmission of infection. ${ }^{17}$ In this hospital, these disinfectants are used for equipment such as laparoscopes, gastroscopes, endotracheal tubes and other endoscopes, which are used in direct contact with a break in skin or mucus membrane or enter a sterile body area. Having residual bacteria after disinfection is therefore not acceptable.

\section{Conclusion}

Overall, the effect of the selected disinfectants is not adequate as residual bacteria of common HAI causing organisms are present on different surfaces after high level disinfectant use. The effectiveness of high level disinfectants on HAI causing bacteria which are isolated from clinical specimens must be regularly monitored on a case-by-case basis to determine whether they possess the antibacterial activity declared by the manufacturer. Further research should be done on other disinfectants to evaluate their effectiveness in the Sri Lankan health care setting.

Conflicts of interest: There are no conflicts of interest. Samples of both disinfectants were received from respective local agents.

Ethics statement: Ethical clearance was obtained from the Ethical Review Committee of General Sir John Kotelawala Defense University and Sri Jayewardenepura General Hospital, Sri Lanka.

\section{References}

1. Guidelines on core components of infection prevention and control programmes at the national and acute health care facility level: WHO; 2018.

Available at https://www.who.int/gpsc/ipc-components/en/

2. Umscheid C, Mitchell M, Doshi J, et al. Estimating the proportion of healthcare-associated infections that are reasonably preventable and the related mortality and costs. Infection Control and Hospital Epidemiology 2011; 32(02):101-114.

doi: https://doi.org/10.1086/657912 
3. Lamarsalle L, Hunt B, Schauf M, et al. Evaluating the clinical and economic burden of healthcare-associated infections during hospitalization for surgery in France. Epidemiology and Infection 2013; 141(12):2473-2482. doi: https://doi.org/10.1017/S0950268813000253

4. Kramer A, Schwebke I, Kampf G. How long do nosocomial pathogens persist on inanimate surfaces? A systematic review. BMC Infectious Diseases 2006; 6(1):Article number: 130 doi: https://doi.org/10.1186/1471-2334-6-130

5. Kawamura-Sato K, Wachino J, Kondo T, et al. Correlation between reduced susceptibility to disinfectants and multidrug resistance among clinical isolates of Acinetobacter species. Journal of Antimicrobial Chemotherapy 2010; 65(9):1975-1983. doi: https://doi.org/10.1093/jac/dkq227

6. Vali L, Davies S, Lai L, et al. Frequency of biocide resistance genes, antibiotic resistance and the effect of chlorhexidine exposure on clinical methicillin-resistant Staphylococcus aureus isolates. Journal of Antimicrobial Chemotherapy 2008; 61(3):524-532. doi: https://doi.org/10.1093/jac/dkm520

7. BS EN 14561: Chemical disinfectants and antiseptics. Quantitative carrier test for the evaluation of bactericidal activity for instruments used in the medical area. Test method and requirements (phase 2, step 2). British Standards Institute 2006.

8. Suetens C, Latour K, Karki T, et al. Prevalence of healthcare-associated infections estimated incidence and composite antimicrobial resistance index in acute care hospitals and long-term care facilities: results from two European point prevalence surveys, 2016 to 2017. Eurosurveillance 2018; 23(46). doi: 10.2807/1560-7917.ES.2018.23.46.1800516

9. Agrawal R, Gupta D, Ray P, et al. Epidemiology, risk factors and outcome of nosocomial infections in a Respiratory Intensive Care Unit in North India. Journal of Infection 2006; 53(2):98-105. doi: https://doi.org/10.1016/j.jinf.2005.10.021

10. Khan H, Baig F, Mehbood R. Nosocomial infections, epidemiology, prevention and control surveillance. Asian Pacific Journal of Tropical Biomedicine 2017; 5:478-482. doi: https://doi.org/10.1016/j.apjtb.2017.01.019

11. Rutala W, Weber D. Disinfection of endoscopes: review of new chemical sterilants used for high-level disinfection. Infection Control and Hospital Epidemiology 1999; 20(01):69-76. doi: https://doi.org/10.1086/501544

12. Nasr A, Mostafa M, Arnaout $\mathrm{H}$, et al. The effect of exposure to sub-inhibitory concentrations of hypochlorite and quaternary ammonium compounds on antimicrobial susceptibility of Pseudomonas aeruginosa. American Journal of Infection Control 2018; 46(7):57-63. doi: https://doi.org/10.1016/j.ajic.2018.04.201

13. Schedler K, Assadian O, Brautferger U, et al. Proposed phase 2/ step 2 in-vitro test on basis of EN 14561 for standardized testing of the wound antiseptics PVP-iodine, chlorhexidine digluconate, polihexanide and octenidine dihydrochloride. BMC Infectious Diseases 2017; 17(1). doi: 10.1186/s12879-017-2220-4

14. Klapper I, Rupp C, Cargo R. Viscoelastic fluid description of bacterial biofilm material properties. Biotechnology and Bioengineering 2002; 80(3):289-296. doi: 10.1002/bit.10376

15. Espinal P, Martí S, Vila J. Effect of biofilm formation on the survival of Acinetobacter baumannii on dry surfaces. Journal of Hospital Infection 2012; 80(1):56-60. doi: https://doi.org/10.1016/j.jhin.2011.08.013

16. Kampf G, Bloß R, Martiny H. Surface fixation of dried blood by glutaraldehyde and peracetic acid. Journal of Hospital Infection 2004; 57(2):139-143. doi: 10.1016/j.jhin.2004.02.004

17. CDC.gov. Healthcare-associated infections HAI: CDC; 2018. Available at: https://www.cdc.gov/hai/index.html 